Copyright (C) 2021 by Cherkas Global University

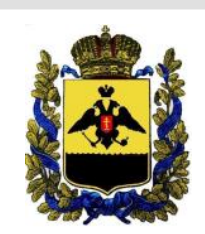

Published in the USA

Bylye Gody

Has been issued since 2006.

E-ISSN: $2310-0028$

2021. 16(4): 1826-1834

DOI: $10.13187 / \mathrm{bg} .2021 .4 .1826$

Journal homepage:

https://bg.cherkasgu.press

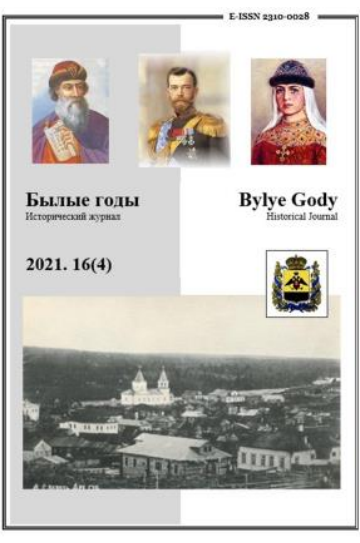

\title{
The City and the Intellectual Class: Socio-Political Interconditionality in North Kazakhstani Region on the cusp of the XIX - XX c.
}

\author{
Gulmira Zh. Sultangazy a, Lepuda K. Mukatayeva a, Zhaslan Ye. Nurbayev b, * \\ a M.S. Narikbayev KAZGUU University, Kazakhstan \\ b L.N. Gumilyov Eurasian National University, Kazakhstan
}

\begin{abstract}
City and urban environment as a multifunctional space play an important role in creation of social processes. Since it's formation the city has become the focal point for innovations and a place where ideas are generated that change not only the landscape, but also the worldview in general. Kazakhstani cities at the turn of XIX-XX centuries during a long time has played a role of administrative and trade units. Integration of marginal cities into the system of socio-economical relations of empire brought to a formation of conditions where citizens become active not only in economic, but also in social aspect. Political segment of the city developed in the context of all-Russian situation. Systematic crisis of the XIX-XX c. required new formats of fighting for their rights. National intellectual class became one of the main subjects of urban environment and develops their own style of struggle which was expressed through cultural enlightenment and political activity.

Complex study of the city environment through the historical lens allows to gasp the nature of changes occurring with the society and the state and identify possible scenarios of their interaction and development perspectives. The article made an attempt to throw light interconditionality of cityscape and intellectual class in the context of local processes. These processes are related to the formation of political space in the colonial city and the influence of city on social activity of national intellectual class. The article uses the materials of Kazakhstani and Russian archives, document of regional archives, such as the archive of Kostanay city and North-Kazakhstan region. The methodological basis of the research are institutional and frontier approach, which allow to identify the degree of urban environment and city space influence on formation of national intellectual class. Also, it allows to study the evolution and development of political ideas and focus of Kazakh intellectual class in the end of XIX beginning XX c. in the conditions of building relationship system between the empire and national borders. Historical and genetical method is also applied in the present study, which allows to consider the challenges of the development and identify patterns.

Keywords: city, intellectual class, cultural spaces, political space, political activities of the intelligentsia, public spaces, national outskirts, Kostanay, Petropavlovsk, Akmolinsk.

\section{1. Введение}

Рубеж XIX-XX веков в истории Казахстана отмечен противоречивыми процессами инноваций номадического общества, охватывающими все сферы социально-экономической и политической действительности. В этот период наблюдается становление новой социальной группы, выполнявшей связующие функции между традиционалистским этносом и имперскими властными структурами. Содержание их деятельности создало предпосылки для формирования интеллектуального поля поиска альтернативных путей адаптации общества к изменившимся реалиям.
\end{abstract}

\footnotetext{
${ }^{*}$ Corresponding author

E-mail addresses: zhaslannurbayev@gmail.com (Zh.Ye. Nurbayev) 
Очевидно, что оформление гражданских позиций и активизация политической деятельности казахских интеллектуалов проходили в городской среде. Колониальные города, созданные в результате активного казачьего продвижения, выполняли прежде всего административные функции. Значительную часть горожан составляли казачество, купечество, ремесленники и часть населения, занятая в отраслях по переработке сельскохозяйственного сырья.

Город при всей своей функциональности был минимально интегрирован в политический контекст развития империи. Интеллигенция способствовала развитию общественных процессов через открытие библиотек, участие в научных организациях. Политизация городов, несомненно, была связана с бурными событиями начала $\mathrm{XX}$ века и содержательной деятельностью интеллектуалов.

В данной статье предпринята попытка осветить процесс влияния города на политизацию интеллигенции и формирование в городах Северного Казахстана политического пространства, под которым мы будем подразумевать среду, способствующую активному вовлечению горожан в политические и гражданские процессы рубежа XIX-XX вв. С одной стороны, исследование позволит проследить генезис взаимоотношений горожан, прежде всего интеллигенции с властью, с другой мы актуализируем город как пространство в политическом измерении.

\section{2. Материалы и методы}

Документальным материалом послужили фонды Оренбургского областного архива (ГАОО), Российского государственного исторического архива (РГИА), Центрального государственного архива Республики Казахстан (ЦГА РК). Значительный объем составляют документы, характеризующие деятельность интеллигенции начала XX века. Хронологически обозначенный период совпадает с революцией 1905 г., выборами и работой в Государственной Думе, а также с активизацией национально-освободительного движения: РГИА, ф. 1278 «Государственная Дума I, II, III и IV созывов» и ЦГА РК, ф. 17 «Тургайский областной комиссариат Временного правительства», ф. 18 «Тургайская Управа Временного правительства». Также документальной основой послужили фонды Государственных архивов Костанайской и Северо-Казахстанской областей, детально отражающие материалы по открытию и функционированию городских библиотек, статистических управлений, различных культурных и общественных учреждений. Изучение данного массива документов позволяет проследить динамику качественных изменений общественного сознания и степени вовлеченности горожан в общественные и политические процессы.

Теоретико-методологическая база исследования представляет собой использование различных подходов, методов и оценок, используемых в междисциплинарных исследованиях. В работе применяются такие методы и инструменты, как институциональный, фронтирный подходы, которые позволили определить роль и место социальных институтов, городской среды в формировании национальной интеллигенции, рассмотреть развитие и трансформацию политических взглядов и установок казахской интеллигенции в конце XIX - начале XX вB. в контексте интеграции казахского этноса в общероссийское имперское пространство.

Также в работе были использованы конкретно-исторические методы - историкосравнительный, историко-системный, историко-генетический, применение которых позволило проанализировать широкий круг источников и историографического материала, определить особенности процессов взаимовлияния и взаимообусловленности города и интеллигенции в начале XX века и факторов, повлиявших на данный процесс.

\section{3. Обсуждение}

Город как объект изучения чаще всего рассматривается с архитектурной, экономической точек зрения. В последнее время политическое измерение города, взаимодействие власти и активных акторов становится актуальным в контексте «модели анализа власти на уровне социума». Город постепенно в научных исследованиях стал рассматриваться как пространство, способное создавать условия для политизации человека и его вовлеченности в общественные и гражданские процессы. Е. Трубина, отмечая общественную значимость города, считает, что «это главное пространство, где происходят социальные изменения, и ключевое место, в котором создается социальная теория» (Трубина, 2011: 15).

Город активирует деятельность человека в данном направлении интенсивнее, чем сельская местность, в которой хозяйственный фактор куда важнее, чем политический. Так, Б. Вальденфельс, обсуждая различные типы понимания повседневности, характеризует город как «место обмена и обмена мнениями» (Плотичкина, 2012: 154). В советской историографии политическое пространство как формулировка и как отдельный объект не использовалось и не изучалось. В казахстанской историографии внимание получила деятельность национальной интеллигенции без привязки к локации. Наиболее политизированным пространством в Российской империи в начале XX века, несомненно, был город. Здесь сформировалось сообщество интеллектуалов, чья деятельность в значительной мере определяла развитие страны. Историография вопроса представлена исследованиями, отражающими развитие города как в экономическом, так и в

$$
-1827-
$$


политическом контекстах. В них также актуализируются различные аспекты деятельности интеллектуалов города как такового.

В попытках выявления тенденций формирования политических позиций и политической социализации лидеров исследователь О. Протасова выявляет ряд факторов, влиявших на этот процесс, среди которых особое место занимают городские образовательные учреждения (Протасова, 2021: 1410). По мнению Е. Самойловой, важную роль в формировании культурной среды в городах национальных окраин играли представители интеллигенции (Самойлова, 2006: 149), у которой был запрос на эстетику города, выраженный не только в существовании театра, библиотек, но и среды, удовлетворяющей ее интеллектуальные и духовные потребности. При этом автор признает, что возможности интеллигенции были ограничены, отсюда очевидное отставание провинциальных городов.

Проблема взаимодействия города и интеллигенции была поднята коллективом авторов Т. Нефедовой и др. Город рассматривается ими в качестве «царства несвободы». Он является средоточием бездушной имперской бюрократии с характерным прессингом на индивидуальность (Нефедова, 2016: 154).

Современная казахстанская историография при открытости и доступе к архивным данным заметно расширила проблематику исследовательского поля. Городская тематика все еще является новым направлением, но тем не менее есть работы, которые предопределили его развитие. Это труды таких авторов, как Ж. Касымбаев (Касымбаев, 1990), Н. Алексеенко (Алексеенко, 1981), М. Койгельдиев (Койгельдиев, 1994), Д. Аманжолова (Аманжолова, 2009), Г. Алпыспаева (Алпысбаева и др., 2016) и др. Их работы освещают как городскую историю, так и деятельность интеллигенции, сформировали проблемное поле, но без выявления их взаимосвязи и взаимовлияния.

Роль казахской интеллигенции начала XX века безусловна, она стала ведущей силой на политической арене края. Но имеет место быть некритический подход в оценках ее деятельности. Казахстанскими исследователями опубликована статья, где обозначена проблематика представленности казахских интеллектуалов в политической и общественной жизни края независимо от их политических предпочтений (Бисенова, Мукушева, 2020). Действительно, несмотря на то, что численность интеллигенции была на критически низком уровне, тем не менее в идейном отношении она была разобщенной, что не есть плохо, а скорее демонстрирует качество. Однако в современной казахстанской историографии большое внимание уделяется ее либеральному крылу.

И. Агеев считает, что городское пространство является совокупностью исторически обусловленных ролей и сценариев взаимодействия социальных и экономических субъектов (Агеев, 2014: 79-84). В этом случае у интеллигенции особая роль по формированию культурной среды.

«Этнизация городских пространств» как важное положение в трудах иркутских ученых (Дятлов, Григоричев, 2013: 573) корреспондируется с ролью казахских интеллектуалов в городах северного Казахстана.

Сегодня взаимодействие города и интеллигенции рассматривается в контексте различных методологических подходов. Например, казахстанскими учеными предпринята попытка исследовать феномен города через историю повседневности. Использование этого метода позволяет более глубоко рассмотреть сложные процессы городской жизни в исследованиях К. Абдрахмановой (Абдрахманова, 2006), 3. Сактагановой (Сактаганова, 2017), К. Медеуовой (Медеуова, 2016; Медеуова, 2018).

Таким образом, казахстанский историографический массив представлен работами, отражающими те или иные аспекты урбан истории. Вместе с тем не в полной мере освещены вопросы взаимовлияния и взаимообусловленности города и социальных институтов или многочисленных социальных групп.

\section{4. Результаты}

Политическое развитие Казахстана, в том числе и города, происходило в контексте общероссийской социально-политической ситуации. К обозначенному периоду Казахстан представлял собой окраину российской империи с набором типичных социально-экономических проблем. Ситуация осложнялась остротой нерешенного аграрного вопроса. Традиционный уклад не вписывался в систему капиталистических отношений, в которые экономика Казахстана была полностью интегрирована после ряда административных реформ. Казахи оказались не подготовлены ни в психологическом, ни в материальном аспектах к изменениям экономического порядка. Но земельная реформа 1861 года, впоследствии Положение о переселении 1868 года и более поздние указы ускорили масштабное переселение русских безземельных крестьян в степи. К началу ХХ века казахское население ведет активную борьбу против колонизации и по восстановлению политических и экономических прав. Однако применяемые инструменты политической борьбы морально устарели. Казахский социум при всей активности, мы имеем в виду протестные настроения конца XVII - начала $\mathrm{XX}$ веков, не обладал знаниями и умениями, необходимыми для политической борьбы формата начала XX века. Он ставил, главным образом, перед собой задачу экономического освобождения, не предполагая при этом изменений в политическом оформлении. Родовое деление, сопровождавшееся конфликтами, также является показателем неготовности к системной борьбе с обозримым результатом. Политическая реальность начала ХХ века требовала новых форм и лидеров. 
В этот период наблюдается становление социальной группы, выполнявшей связующие функции между традиционалистским этносом и имперскими властными структурами. Содержание их деятельности создало предпосылки для формирования интеллектуального поля поиска альтернативных путей адаптации общества к изменившимся реалиям. Данная группа граждан, этнически связанная с большинством, генетически оставалась наследницей государственноуправленческой структуры номадов, но уже на основе взаимодополняющих друг друга европейских и восточных ценностей. Интеллигенция обозначила местом своей локации и активной деятельности город. Как правило, молодые люди с определенным образовательным цензом возвращались в уездные города, где были созданы условия для их профессиональной реализации.

Наиболее противоречивым в своем решении был вопрос выбора концепции и инструментов борьбы. Также было очевидным, что традиционный формат открытого протеста стихийных выступлений был не только неэффективным, но и сопряжен с рисками людских потерь. Интеллигенция стояла перед задачей поиска объединяющего начала, которое не только не должно быть аналогом архаического миропонимания степняка, но и не обладать модернизированным смыслом, отдаленным от традиционного восприятия кочевником государства и власти. Для степного пространства характерно органическое существование власти и народа и отсутствие пропасти между ними, а она могла возникнуть ввиду глубокой увлеченности представителями интеллигенции западными идеями и наличием социальных различий между интеллигенцией и кочевым обществом. Другими словами, идеи и правопонимание казахских либералов должны были отражать качественное состояние общества, его духовные, материальные, геополитические основы (Казиев, 2015: 77). В идеале образование государственности, его основ должны были быть результатом обоюдного процесса со стороны казахского социума и творческого меньшинства, представленного либерально настроенной интеллигенцией.

Как выше было отмечено, политическое развитие и формирование политической культуры в Казахстане начала XX века происходили в контексте русской политической мысли и действительности. В этот период Россия переживает пик политической активности: развиваются средства массовой коммуникации, наблюдается рост числа библиотек, что влияло на формирование политической культуры. Библиотеки стали тем общественным пространством, где происходила коллаборация городских интеллектуалов и уездные города постепенно приобретали политическое измерение.

Интеллигенция, таким образом, смогла раскрыть свой потенциал как идейных лидеров в городском пространстве, где были возможности для коллаборации и консолидации общественных сил по схожим признакам, что позволило сформировать политическую платформу. Этот процесс был достаточно сложным и по времени длительным. Просветительская деятельность была приоритетной для интеллигенции обозначенного периода в связи с отрицанием открытого протеста, сопряженного с рисками и угрозами для кочевого населения. Этой позиции казахская интеллигенция придерживалась и в период восстания 1916 года, призывая к мирному разрешению вопроса. Город для казахского интеллектуала стал той средой, где он мог проявить свою конкретную гражданскую позицию. Однако окраинные города отличала политическая индифферентность, скорее это были городские поселения, где преимущественная часть населения занималась сельским хозяйством. Городами в классическом понимании в очень приближенном виде их делали общественные пространства: библиотеки, парки, театры, клубы и т.д., то есть такого рода локации, где общественность могла обменяться мнениями, обсудить важные новости и др.

Но гораздо больший эффект для общественного развития и социальной активности горожан был получен через развитие средств массовой информации. Первые газеты были направлены на просветительско-информационное содержание, в то же время они представляли собой и канал коммуникации: бизнеса и горожан, общества и власти, что, собственно, и вело к формированию общественной активности, желанию быть вовлеченным в процессы жизни и деятельности города. Так, в Кустанае в начале XX века в связи с остротой земельного вопроса и большого потока переселенцев появился запрос на информацию о сельском хозяйстве и особенностях его развития в условиях Степного края. Появление такого издания, как «Кустанайское степное хозяйство», вполне закономерно, учитывая, что аграрный вопрос касался всех категорий населения, а также стал причиной экономических и межэтнических конфликтов в регионе. Издание по замыслу его создателей должно было не только разрядить напряженность в этом вопросе, но и выполнять образовательную миссию: знакомить читателей с «передовыми статьями по сельскому хозяйству» (ГАКО. Ф. 1762. Оп. 1. Д. 107. Л. 8-12).

Кстати, первым городским изданием Костаная стала газета «Степные отголоски», целью которой была просветительская деятельность и активация общественной жизни города. «Степные отголоски» должны были выходить 2 раза в неделю при незначительном тираже. Но издание не получило поддержки и было закрыто. До 1910 года жители города в информационном отношении зависели от Оренбурга, Троицка и других городов. Выписывались издания также из СанктПетербурга и Москвы. Но предпочтение отдавалось местным губернским изданиям. Читательская культура для малочисленного города была довольно высокой, выпускалось около ста печатных 
изданий (ГАКО. Ф. 1762. ОП. 1. Д. 107. Л. 11-12). В активно развивающемся в ХІХ веке Петропавловске выписывались как центральные издания - «Журнал Министерства государственного имущества» (Санкт-Петербург), где можно было прочитать «заметку о развитии земледелия у казахов», так и газеты областного значения. Например, в местном периодическом издании «Тобольские губернские ведомости» можно обнаружить сообщение об открытии в Петропавловске табачной фабрики (ГАСКО. Ф. 158. Оп. 1. Д. 50. Л. 36).

Среди горожан появилась привычка, узнавать новости через газеты, вот отрывок из статьи о развитии СМИ в крае: «Теперь он чутко прислушивается к вестям, идущим из сердца России, до того не имевший понятия о газете, теперь он первого встречного расспрашивает, что пишут в газетах» (ГАКО. Ф. 1762. ОП. 1. Д. 107. Л. 25).

В XIX веке создавались собственные типографии в крае. Так, в 1869 году было закуплено в Санкт-Петербурге значительное количество типографского оборудования для создания типографии в городе Верном. В.3. Галиев отмечает, что новая типография в городе начала свою работу в 1869 г. (Галиев, 2007: 262).

Формируются новые практики и модели поведения, которых до начала ХХ века в уездном городе не существовало. Горожанин не только желает узнавать новости, но и готов создавать новости и быть вовлеченным в общественные процессы городской жизни.

Городская тематика также получила отражение на страницах печати, прежде всего отчеты о заседаниях городской думы и хроника общественных событий. Городская дума, ее деятельность и участие в ней горожан являются свидетельством повышения уровня политической культуры. Кустанайская городская дума за все время своего существования смогла не только обозначить, но и решить некоторые городские вопросы.

Газета становится в таком случае инструментом в руках общественности, и через нее решаются проблемы не только города, но и края в целом. Как правило, такие издания не ограничивались узкой проблематикой, а в поле зрения и обсуждений попадали актуальные вопросы (ЦГА РК. Ф. И-25. Оп. 1. Д. 797. Л. 239об.).

Критика действующего режима также имела место. Показательным является следующий факт: в августе 1917 года Кустанайской городской думой было принято решение о переименовании Царской улицы в имени Л. Толстого. Событие вполне ординарное для революционного периода, тем не менее демонстрирует особую актуальность и вовлеченность горожан в общественные процессы (ГАКО. Ф. 1010. ОП. 1. Д. 17. Л. 11).

Политизация городского пространства может проявляться в различных аспектах. Очень важно понимать: какие причины, условия способствовали и какие факторы имели тормозящий эффект для развития политической культуры и формирования политического пространства в городе.

Допустим, удаленность от крупных политических центров и в целом слабые коммуникации являлись сдерживающими факторами в политизации как городского социума, так и города в целом.

Думский период, несмотря на скромную результативность, стал одним из значительных в вопросе оформления политических взглядов казахской интеллигенции. Интегрирование в политическую жизнь российского государства на столь высоком уровне позволило казахам получить опыт ведения дебатов, оппонирования, а также осознать свое место и потенциал в общей картине политической жизни российского государства.

Первые две думы были слишком непродолжительны для того, чтобы решить проблемы, которые накапливались годами. Тем не менее депутаты максимально использовали отпущенное им время и ставили на обсуждение те вопросы, которые не желало рассматривать и решать правительство. Так, А. Беремжанов, Б. Каратаев, Ш. Косшыгулов, Т. Нурекен встретились с главным управителем по делам земледелия и землеустройства князем Б. Васильчиковым по вопросам переселения русских крестьян в степь. Аграрная политика правительства шла вразрез с интересами коренного населения окраин, не считаясь с его обычаями, традициями и хозяйственными особенностями (Озганбай, 2000: 139), тогда как это было важным вопросом, требующим внимания. Актуализация проблемы была связана с новым витком переселенческой политики правительства, против которой выступали не только инородцы, но и крестьяне Сибири. Например, Н. Коншин в одном из своих выступлений в Думе сказал: «Никакие переселения в Сибирь общерусского аграрного вопроса решить нисколько не помогут... Сибиряки с цифрами и фактами в руках могли бы доказать ту крайнюю неточность сведений о свободных для переселения земель, ссылаясь на которую правительство побуждает крестьян двинуться в Азию. В таком громадном общегосударственном деле, как переселение всякие неправильности должны быть моментально исправлены» (Государственная Дума, 1906: 2271-2272).

При этом Н. Коншин не затронул вопросов о незаконном изгнании коренного населения с исконных земель, об экспроприации, проводимой переселенческим управлением. Именно этим проблемам был посвящен запрос на имя председателя Совета министров по поводу незаконного образования переселенческих участков и местных дач в Казахской степи, подписанный 53 депутатами (РГИА. Ф. 1278. Оп. 1. Д. 350. Л. 4). 
Таким образом, впервые в столь широких кругах были высказаны позиции казахских интеллигентов по таким значимым проблемам, как земельная, необходимость реформирования судов и др. И ранее интеллигенты проявляли активность: составлялись петиции, прошения в адрес самых высокопоставленных членов правительства, но в данном случае была возможность донести ситуацию по земельному вопросу казахского народа самой широкой публике. Очевидно, вопросы обсуждались и до созыва Дум, так как казахская интеллигенция провела объединенные съезды в Уральске в декабре 1905 года и Семипалатинске в феврале 1906 года, где она вполне могла обозначить общие позиции по такому значительному вопросу, как земельный.

Поиск общественного согласия на фоне острого политического момента стал возможен благодаря съездам, которые стали площадкой для обсуждения актуальных вопросов. В их работе приняли участие не только интеллигенция, но и представители нового класса казахской торговой буржуазии, кочевая знать в лице биев и аксакалов, чиновники старой администрации, а также члены мусульманского комитета из Казани, представители интеллигенции из других регионов, в основном из азиатской части России (Алаш-Орда, 1992: 21). Собрания прошли в городах Тургае, Верном, Омске, Семипалатинске, Уральске, Оренбурге и др. Количество участников варьировалось от 200 до 500 человек. В содержательной части они были схожими: от поддержки Временного правительства, созыва Учредительного собрания, скорейшего решения земельного вопроса, выработки тактических линий до желания в краткие сроки решить региональные проблемы (Алаш-Орда, 1992: 23). Съезды стали некой вехой в формировании политической культуры и сознания казахского этноса. Ситуация складывалась в пользу либералов, поскольку фактически они стали не только инициаторами, но председательствующей силой в проведении съездов. Этот момент стал наиболее благоприятным для реализации идей казахских интеллигентов. Политическая активность общественности требовала систематизации и конструктивной направленности. В целях оптимизации процесса революционных преобразований либеральная интеллигенция инициировала создание общественных комитетов. Было принято решение о формировании таковых при поддержке известных представителей интеллигенции. Так, в Актюбинский уезд поехал А. Букейханов (ЦГА РК. Ф. 18. Оп. 1. Д. 15. Л. 2).

Еще одним вопросом, который должен был закрепить демократические преобразования, стал вопрос о земстве.

Июльский съезд 1917 года стал переломным моментом в политической жизни Казахстана. Несмотря на то, что в повестке дня стояли вопросы, аналогичные повестке предыдущих областных съездов, тем не менее решения по ним носили исторический характер (Алаш-Орда, 1992: 50). Принятые постановления станут программными установками партии Алаш и разделительной полосой в отношениях с кадетами.

Проблема введения земства в крае стала еще актуальней после февральских событий. В Казахстане в отсутствии земства власть балансировала между общественными организациями и комиссарами. В центральной части России земство было введено во второй половине XIX века. 17 июня 1917 г. было обнародовано постановление Временного правительства о введении земских учреждений в областях Акмолинской, Семипалатинской, Семиреченской, Тургайской и Уральской (ЦГА РК. Ф. 18. Оп. 1. Д. 29. Л. 25).

В Тургайской области вопрос о введении земства обсуждался на заседании областной управы 28 июня 1917 г. (ЦГА РК. Ф. 18. ОП. 1. Д. 29. Л. 25).

Организация уездных земств была поручена существующим в уездах гражданским комитетам. Им было предложено создать специальные комиссии из числа компетентных лиц, которые могли бы оказать пользу при организации уездного земства. В Кустанае вопрос о земстве обсуждался на съезде Кустанайского уездного гражданского комитета 27 августа 1917 г. На съезд явились представители 25 волостей, его председателем единогласно был избран А. Беремжанов (ЦГА РК. Ф. 18. Оп. 1. Д. 8. Л. 91). На повестку дня были вынесены вопросы о выборах в комиссию по введению земства. На этом же съезде путем открытой баллотировки членами комиссии были избраны Шаповалов, Руденко, Мезоненко и другие (ЦГА РК. Ф. 18. Оп. 1. Д. 8. Л. 910б.). Земство стало еще одним приобретением демократических преобразований.

\section{5. Заключение}

Городская интеллигенция, являясь по сути основным субъектом данного процесса, не была монолитна в своей идейной направленности, но это скорее создавало благоприятную основу для политизации и вовлеченности разных ее представителей. Революция 1905 года активизировала национальную интеллигенцию, которая в этот момент пришла к осознанию своей гражданской ответственности за судьбы казахского народа. И ее активность стала проявляться именно в городской среде. Интеллигенция сыграла ощутимую роль в формировании политического пространства. Город в самом начале его зарождения играл прежде всего административную роль. Интеллигентская сущность с ее стремлением к прекрасному и желанию облагородить способствовала появлению библиотек, театральных кружков, проведению музыкальных вечеров и т.д. Таким образом, постепенно в городе созидалось культурное пространство, которое способствовало формированию такой прослойки общества, как интеллигенция. 


\section{6. Благодарности}

This research has been funded by the Science Committee of the Ministry of Education and Science of the Republic of Kazakhstan (Grant No. APo8857378).

\section{Литература}

Абдрахманова, 2006 - Абдрахманова К.К. «История повседневности» в XX-XXI веках. Историографический аспект. Караганда: Издательство КарГУ, 2006. 252 с.

Агеев, 2014 - Агеев И.А. Методологический ресурс исторической урбанистики в современных исследованиях городских пространств // Вестник Томского государственного университета. 2014. № 385. С. $79-84$.

Алаш-Орда, 1992 - Алаш-Орда. Сборник документов. Сост. Мартыненко Н. Алма-Ата: Айкап, 1992. $192 \mathrm{c}$.

Алексеенко, 1981 - Алексеенко Н.В. Население дореволюционного Казахстана (численность, размещение, состав, 1870-1914 гг.). Алма-Ата: Наука, 1981. 112 с.

Алпысбаева и др., 2016 - Алпыспаева Г.А., Саяхимова Ш.Н., Туксаитова Р.О. Культурное пространство Акмолы, Целинограда, Астаны: история становления и развития. Астана: Издательство КАТУ им. С.Сейфуллина, 2016. 206 с.

Аманжолова, 2009 - Аманжолова Д. На изломе. Алаш в этнополитической истории Казахстана. Алматы, 2009. 412 с.

Бисенова, Мукушева, 2020 - Бисенова А., Мукушева А. Колониальные интеллектуалы: между просвещенческой и представительской ролью // Новое литературное обозрение. 2020. № 6. [Электронный pecypc]. URL: https://www.nlobooks.ru/magazines/novoe_literaturnoe_obozrenie/166_nlo_ 6_2020/article/22963/ (дата обращения: 17.07.2021).

Галиев, 2007 - Галиев В.З. Верненская типография и начало издания «Семиреченских областных ведомостей» / Библиотековедение, библиография, книговедение. Сборник научных статей. Вып. 18. Алматы: Национальная библиотека Республики Казахстан, 2007. 262 с.

ГАКО - Государственный архив Костанайской области.

ГАСКО - Государственный архив Северо-Казахстанской области.

Государственная Дума, 1906 - Государственная Дума. Стенографические отчеты. 1906. Сессия 2. C. $2271-2272$.

Дятлов, Григоричев, 2013 - Дятлов В., Григоричев К. Переселенческое общество Азиатской России: миграции, пространства, сообщества. Иркутск: Оттиск, 2013. 624 с.

Казиев, 2015 - Казиев C. Ислам, тюркизм и становление казахской этносоциальной идентичности в начале XX века // Вестник СВФУ. 2015. Том 12. № 1. С. 75-83.

Касымбаев, 1990 - Касымбаев Ж.К. Города Восточного Казахстана в 1861-1917 г.: (социальноэкономический аспект). Алма-Ата: Ғылым, 1990. 184 с.

Койгельдиев, 1994 - Койгельдиев М. Қазақ демократиялық интеллигенциясының 1905-1917 жылдардағы қоғамдық-саяси кызметі. Тарих ғылымдарының докторы ғылыми дәрежесін алу үшін дайындалған диссертация. Алматы. 1994.

Медеуова, 2016 - Медеуова К.А. Карты памяти Астаны: Очерки и интервью по антропологии города. Астана: ТОО Мастер По, 2016. 84 с.

Медеуова, 2018 - Медеуова К.А. О чем хотят помнить в городах (Анализ современной коммеморативной политики в Казахстане) / Женщины-ученые Беларуси и Казахстана: Сборник материалов Международной научно-практической конференции. Минск, 2018. С. 307-309.

Нефедова, 2016 - Нефедова Т.Г., Николаева У.Г., Покровский Н.Е. Интеллигенция в пространстве внегородской России // Социологические исследования. 2016. № 12. С. 152-161.

Озганбай, 2000 - Озганбай О. Государственная Дума и Казахстан. 1905-1917. Алматы: Арыс, 2000. 284 c.

Плотичкина, 2012 - Плотичкина Н. Город как пространство политической повседневности // Человек. Сообщество. Управление. 2012. № 1. С. 154.

Protasova, 2021 - Protasova O.L. Ideological Self-Determination and Inter-Party Rotations in the Russian Democratic Environment (late XIX - early XX centuries) // Bylye Gody. 2021. 16(3): 1409-1420.

РГИА - Российский государственный исторический архив.

Сактаганова, 2017 - Сактаганова 3.Г. Экономическая модернизация Казахстана. 1946-1970 гг. Караганда: Изд-во КарГУ, 2017. 365 с.

Самойлова, 2006 - Самойлова E.B. Роль интеллигенции в развитии социокультурного пространства губернских городов западной Сибири во второй половине XIX века // Известия Челябинского научного центра. 2006. Вып. 4 (34). С. 148-152.

Трубина, 2011 - Трубина Е.Н. Город в теории: опыт осмысления пространства. М.: Новое литературное обозрение, 2011. 520 с.

ЦГА РК - Центральный государственный архив Республики Казахстан. 


\section{References}

Abdrahmanova, 2006 - Abdrahmanova, K.K. (2006). «Istoriya povsednevnosti» v XX-XXI vekah. Istoriograficheskij aspekt. ["The history of everyday life" in the XX-XXI centuries. Historiographical aspect]. Karaganda: Izdatel'stvo KarGU, 252 p. [in Russian]

Ageev, 2014 - Ageev, I.A. (2014). Metodologicheskij resurs istoricheskoj urbanistiki v sovremennyh issledovaniyah gorodskih prostranstv [Methodological resource of historical urbanism in modern studies of urban spaces]. Vestnik Tomskogo gosudarstvennogo universiteta. 385: 79-84. [in Russian]

Alash-Orda, 1992 - Alash-Orda. (1992). Sbornik dokumentov [Alash-Orda. Collection of documents]. Sost. Martynenko N. Alma-Ata: Ajkap, 192 p. [in Russian]

Alekseenko, 1981 - Alekseenko, N.V. (1981). Naselenie dorevolyucionnogo Kazahstana (chislennost', razmeshchenie, sostav, 1870-1914 gg.) [Population of pre-revolutionary Kazakhstan (number, location, composition, 1870-1914)]. Alma-Ata: Nauka, 112 p. [in Russian]

Alpysbaeva i dr., 2016 - Alpyspaeva, G.A., Sayahimova, Sh.N., Tuksaitova, R.O. (2016). Kul'turnoe prostranstvo Akmoly, Celinograda, Astany: istoriya stanovleniya i razvitiya [Cultural space of Akmola, Tselinograd, Astana: the history of formation and development]. Astana: Izdatel'stvo KATU im. S.Sejfullina, 206 p. [in Russian]

Amanzholova, 2009 - Amanzholova, D. (2009). Na izlome. Alash v etnopoliticheskoj istorii Kazahstana [On the break. Alash in the ethnopolitical history of Kazakhstan]. Almaty, 412 p. [in Russian]

Bisenova, Mukusheva, 2020 - Bisenova A., Mukusheva A. (2021). Kolonial'nye intellektualy: mezhdu prosveshchencheskoj i predstavitel'skoj rol'yu [Colonial intellectuals: between enlightenment and representative role]. Novoe literaturnoe obozrenie. 6. [Electronic resource]. URL: https://www.nlobooks.ru/ magazines/novoe_literaturnoe_obozrenie/166_nlo_6_2020/article/22963/ (date of access: 17.07.2021). [in Russian]

CGA RK - Central'nyj gosudarstvennyj arhiv Respubliki Kazahstan [Central State Archive of the Republic of Kazakhstan].

Dyatlov, Grigorichev, 2013 - Dyatlov, V., Grigorichev, K. (2013). Pereselencheskoe obshchestvo Aziatskoj Rossii: migracii, prostranstva, soobshchestva [Resettlement Society of Asian Russia: migrations, spaces, communities]. Irkutsk: Ottisk, 624 p. [in Russian]

Galiev, 2007 - Galiev, V.Z. (2007). Vernenskaya tipografiya i nachalo izdaniya "Semirechenskih oblastnyh vedomostej" [Vernenskaya printing house and the beginning of the publication of the Semirechensk Regional Gazette]. Bibliotekovedenie, bibliografiya, knigovedenie. Sbornik nauchnyh statej. Vyp. 18. Almaty: Nacional'naya biblioteka Respubliki Kazahstan, 262 p. [in Russian]

GAKO - Gosudarstvennyj arhiv Kostanajskoj oblasti [State Archive of Kostanay region]. region].

GASKO - Gosudarstvennyj arhiv Severo-Kazahstanskoj oblasti [State Archive of the North Kazakhstan

Gosudarstvennaya Duma, 1906 - Gosudarstvennaya Duma. Stenograficheskie otchety [The State Duma. Verbatim reports]. 1906. Sessiya 2. Pp. 2271-2272. [in Russian]

Kaziev, 2015 - Kaziev, S. (2015). Islam, tyurkizm i stanovlenie kazahskoj etnosocial'noj identichnosti v nachale XX veka [Islam, Turkism and the formation of Kazakh ethno-social identity in the early XXth century]. Vestnik SVFU. 12(1): 75-83. [in Russian]

Kasymbaev, 1990 - Kasymbaev, Zh.K. (1990). Goroda Vostochnogo Kazahstana v 1861-1917 g.: (social'no- ekonomicheskij aspekt) [Cities of East Kazakhstan in 1861-1917: (socio-economic aspect)]. AlmaAta: Fylym, 184 p. [in Russian]

Kojgel'diev, 1994 - Kojgel'diev, M. (1994). Қазақ demokratiyalyқ intelligenciyasynyң 1905-1917 zhyldardaғу қоғатдук-sayasi kyzmeti [Socio-political activity of the Kazakh Democratic intelligentsia in 1905-1917]. Tarih ғylymdarynyң doktory ғylymi dərezhesin alu yshin dajyndalғan dissertaciya. Almaty. [in Kazakh]

Medeuova, 2016 - Medeuova, K.A. (2016). Karty pamyati Astany: Ocherki i interv'yu po antropologii goroda [Memory cards of Astana: Essays and interviews on the anthropology of the city]. Astana: TOO Master Po, 84 p. [in Russian]

Medeuova, 2018 - Medeuova, K.A. (2018). O chem hotyat pomnit' v gorodah (Analiz sovremennoj kommemorativnoj politiki $\mathrm{v}$ Kazahstane) [What they want to remember in cities (Analysis of modern commemorative policy in Kazakhstan)]. Zhenshchiny-uchenye Belarusi i Kazahstana: sbornik materialov Mezhdunarodnoj nauchno-prakticheskoj konferencii. Minsk. Pp. 307-309. [in Russian]

Nefedova, 2016 - Nefedova, T.G., Nikolaeva, U.G., Pokrovskij, N.E. (2016). Intelligenciya v prostranstve vnegorodskoj Rossii [Intelligentsia in the space of extra-urban Russia]. Sociologicheskie issledovaniya. 12: 152-161. [in Russian]

Ozganbaj, 2000 - Ozganbaj, O. (2000). Gosudarstvennaya Duma i Kazahstan. 1905-1917 [The State Duma and Kazakhstan. 1905-1917]. Almaty: Arys, 284 p. [in Russian]

Plotichkina, 2012 - Plotichkina, N. (2012). Gorod kak prostranstvo politicheskoj povsednevnosti [The city as a space of political everyday life]. Chelovek. Soobshchestvo. Upravlenie. 1: 154. [in Russian]

Protasova, 2021 - Protasova, O.L. (2021). Ideological Self-Determination and Inter-Party Rotations in the Russian Democratic Environment (late XIX - early XX centuries). Bylye Gody. 16(3): 1409-1420. 
RGIA - Rossijskij gosudarstvennyj istoricheskij arhiv [Russian State Historical Archive].

Saktaganova, 2017 - Saktaganova, Z.G. (2017). Ekonomicheskaya modernizaciya Kazahstana. 19461970 gg. [Economic modernization of Kazakhstan. 1946-1970]. Karaganda: Izd-vo KarGU, 365 p. [in Russian]

Samojlova, 2006 - Samojlova, E.V. (2006). Rol' intelligencii v razvitii sociokul'turnogo prostranstva gubernskih gorodov zapadnoj Sibiri vo vtoroj polovine XIX veka [The role of the intelligentsia in the development of the socio-cultural space of the provincial cities of Western Siberia in the second half of the XIXth century]. Izvestiya Chelyabinskogo nauchnogo centra. 4(34): 148-152. [in Russian]

Trubina, 2011 - Trubina, E.N. (2011). Gorod v teorii: opyt osmysleniya prostranstva [The city in theory: the experience of understanding space]. M.: Novoe literaturnoe obozrenie, 520 p. [in Russian]

\title{
Город и интеллигенция: общественно-политическая взаимообусловленность в Северном Казахстане на рубеже XIX-XX веков
}

\author{
Гулмира Жолмагамбеткызы Султангазы а, Лепуда Каримкызы Мукатаева а, \\ Жаслан Есеевич Нурбаев b, * \\ а Университет КАЗГЮУ имени М.С. Нарикбаева, Казахстан \\ b Евразийский национальный университет имени Л.Н. Гумилева, Казахстан
}

Аннотация. Город и городская среда, являясь полифункциональным пространством, играют важную роль в развитии общественных процессов. С момента своего возникновения город стал концентратом инноваций и пространством генерации идей, меняющих не только ландшафт, но и миропонимание в целом. Казахстанские города рубежа XIX-XX вв. на протяжении длительного времени играли роль административных, торговых единиц. Интегрирование городов национальных окраин в систему социально-экономических отношений империи привели к формированию условий для активности гражданина не только в экономическом, но и общественных аспектах. Политический сегмент города развивался в контексте общероссийской ситуации. Системный кризис периода XIX$\mathrm{XX}$ вв. требовал новых форматов борьбы за свои права. Национальная интеллигенция становится одним из основных субъектов городской среды и вырабатывает свой стиль борьбы, выраженный в симбиозе культурно-просветительской и политической деятельности.

Комплексное изучение городской среды в историческом разрезе позволяет понять природу изменений, в которых находится общество и государство и определить возможные сценарии их взаимодействия и перспектив развития. В статье предпринята попытка осветить взаимообусловленность городского пространства и интеллигенции в контексте процессов, связанных с формированием в колониальном городе политического пространства и влияния города на общественную активность национальной интеллигенции. В статье использованы материалы казахстанских и российских архивов, документы из региональных архивов, таких как архивы Костанайской и Северо-Казахстанской областей. Методологической основой исследования выступили институциональный и фронтирный подходы, позволившие определить степень влияния городской среды и городского пространства на формирование национальной интеллигенции, а также изучить эволюцию политических идей и ориентиров казахской интеллигенции в конце XIX - начале XX вв. в условиях выстраивания системы взаимоотношений империи с национальными окраинами. Одним из методов данного исследования выступил историко-генетический, позволяющий рассмотреть проблематику в ее развитии и выявить закономерности.

Ключевые слова: город, интеллигенция, культурная среда, политическое пространство, политическая деятельность интеллигенции, общественные пространства, национальные окраины, Костанай, Петропавловск, Акмолинск.

\footnotetext{
${ }^{*}$ Корреспондирующий автор

Адреса электронной почты: zhaslannurbayev@gmail.com (Ж.Е. Нурбаев) 